LAWRENCE LIVERMORE N A T IO N A L LABORATORY
Simulation of Nitrate Biogeochemistry and Reactive Transport in a California Groundwater Basin

S. F. Carle, A. F. B. Tompson, W. W. McNab, B. K. Esser, G. B. Hudson, J. E. Moran, H. R. Beller, S. R. Kane

January 16, 2004

Computational Methods in Water Resources 2004 International Conference Chapel Hill, NC, United States June 13, 2004 through June 17, 2004 
This document was prepared as an account of work sponsored by an agency of the United States Government. Neither the United States Government nor the University of California nor any of their employees, makes any warranty, express or implied, or assumes any legal liability or responsibility for the accuracy, completeness, or usefulness of any information, apparatus, product, or process disclosed, or represents that its use would not infringe privately owned rights. Reference herein to any specific commercial product, process, or service by trade name, trademark, manufacturer, or otherwise, does not necessarily constitute or imply its endorsement, recommendation, or favoring by the United States Government or the University of California. The views and opinions of authors expressed herein do not necessarily state or reflect those of the United States Government or the University of California, and shall not be used for advertising or product endorsement purposes. 


\title{
Simulation of Nitrate Biogeochemistry and Reactive Transport in a California Groundwater Basin
}

\author{
S. F. Carle ${ }^{\text {* }}$, A. F. B. Tompson ${ }^{\mathrm{a}}$, W. W. McNab ${ }^{\mathrm{b}}$, B. K. Esser ${ }^{\mathrm{c}}$, G. B. Hudson ${ }^{\mathrm{c}}$, J. E. \\ Moran $^{\mathrm{c}}$, H. R. Beller ${ }^{\mathrm{b}}$, S. R. Kane ${ }^{\mathrm{b}}$ \\ ${ }^{a}$ Environmental Science Division, L-208 \\ ${ }^{\mathrm{b}}$ Environmental Restoration Division, L-542 \\ ${ }^{\mathrm{c} C h e m i c a l ~ B i o l o g y}$ and Nuclear Science Division, L-231 \\ Lawrence Livermore National Laboratory, PO Box 808, Livermore CA 94551 USA
}

Nitrate is the number one drinking water contaminant in the United States. It is pervasive in surface and groundwater systems, and its principal anthropogenic sources have increased dramatically in the last 50 years. In California alone, one third of the public drinking-water wells has been lost since 1988 and nitrate contamination is the most common reason for abandonment. Effective nitrate management in groundwater is complicated by uncertainties related to multiple point and non-point sources, hydrogeologic complexity, geochemical reactivity, and quantification of dentrification processes. In this paper, we review an integrated experimental and simulation-based framework being developed to study the fate of nitrate in a $25 \mathrm{~km}$-long groundwater subbasin south of San Jose, California, a historically agricultural area now undergoing rapid urbanization with increasing demands for groundwater. The modeling approach is driven by a need to integrate new and archival data that support the hypothesis that nitrate fate and transport at the basin scale is intricately related to hydrostratigraphic complexity, variability of flow paths and groundwater residence times, microbial activity, and multiple geochemical reaction mechanisms. This study synthesizes these disparate and multi-scale data into a three-dimensional and highly resolved reactive transport modeling framework.

\section{BACKGROUND}

Nitrate contamination is pervasive in surface and groundwater systems and is a growing problem in California. Greater than 40 percent of the State's population uses groundwater for at least a portion of their domestic needs, and some cities, such as Fresno, Davis, and

${ }^{*}$ This work was conducted under the auspices of the US Department of Energy by the University of California, Lawrence Livermore National Laboratory under contract W-7405-Eng-48. 
Lodi in the Central Valley, rely solely on groundwater. Since 1984, roughly 8,600 out of 25,000 wells in the State have been shut down, primarily because of nitrate contamination. About 10 percent of the currently operating public wells produce water that exceeds the regulatory drinking water standard $(10 \mathrm{mg} / \mathrm{L}$ as $\mathrm{N})$, and a much larger fraction produce water approaching this standard. As the population increases over the next 20 years, the loss of groundwater resources due to nitrate contamination will become an increasingly severe water supply issue [1]. Nitrate issues also affect the planned use of groundwater basins to store water in lieu of above-ground reservoirs [2].

Nitrate contamination is commonly viewed as intractable because it is ubiquitous, has multiple sources, and is expensive to treat. Contamination of groundwater is particularly problematic because aquifers have long response times (years to decades), and are heterogeneous and difficult to characterize. In California, the main anthropogenic activities that contribute nitrate to groundwater - fertilizers, confined animal feeding operations, and septic systems - are a legacy of commerce and growth over the last half-century, yet remain vital to the economic future of the State. Notably, the actual economic impacts of contamination, including the need to blend or treat water supplies, abandon wells, or secure alternative sources, are not well documented or understood.

Management of nitrate contamination requires quantitative assessments of (1) the source, distribution, and evolution of nitrate concentrations in affected aquifers, (2) the economic dimensions of the problem to implement cost-effective remediation, and (3) impact of land and water management practices that have been designed to reduce nitrate loading in order to implement effective source mitigation. All three goals require a fundamental understanding of fixed nitrogen transport and chemistry in the saturated zone on a basin scale.

The biogeochemical cycling of nitrogen between source areas near the ground surface and the vadose and saturated zones is complex and can be microbially mediated [3-6]. In oxic groundwater regimes, nitrate is anionic with no appreciable sorption. Microbial denitrification in the saturated zone facilitates the conversion of nitrate to dissolved molecular nitrogen $\left(\mathrm{N}_{2}\right)$, and is the ultimate sink for nitrate under low oxygen conditions. Characterizing the microbial controls and the kinetics of denitrification is essential to developing accurate reactive transport models for nitrate in groundwater. Developing such models also requires the ability to accurately characterize and model groundwater flow paths in heterogeneous media at both the field scale and basin scale.

\section{THE LLAGAS SUBBASIN}

This paper reviews the initial development of a basin-wide groundwater flow and transport model to study migration and fate of nitrate in the Llagas groundwater subbasin, situated in a narrow inland valley approximately $20 \mathrm{~km}$ south of San Jose, California (Fig. 1). Nitrate contamination of shallow groundwater is pervasive in may parts of the subbasin as a result of numerous rural and agricultural land uses [8,9]. Over the past 


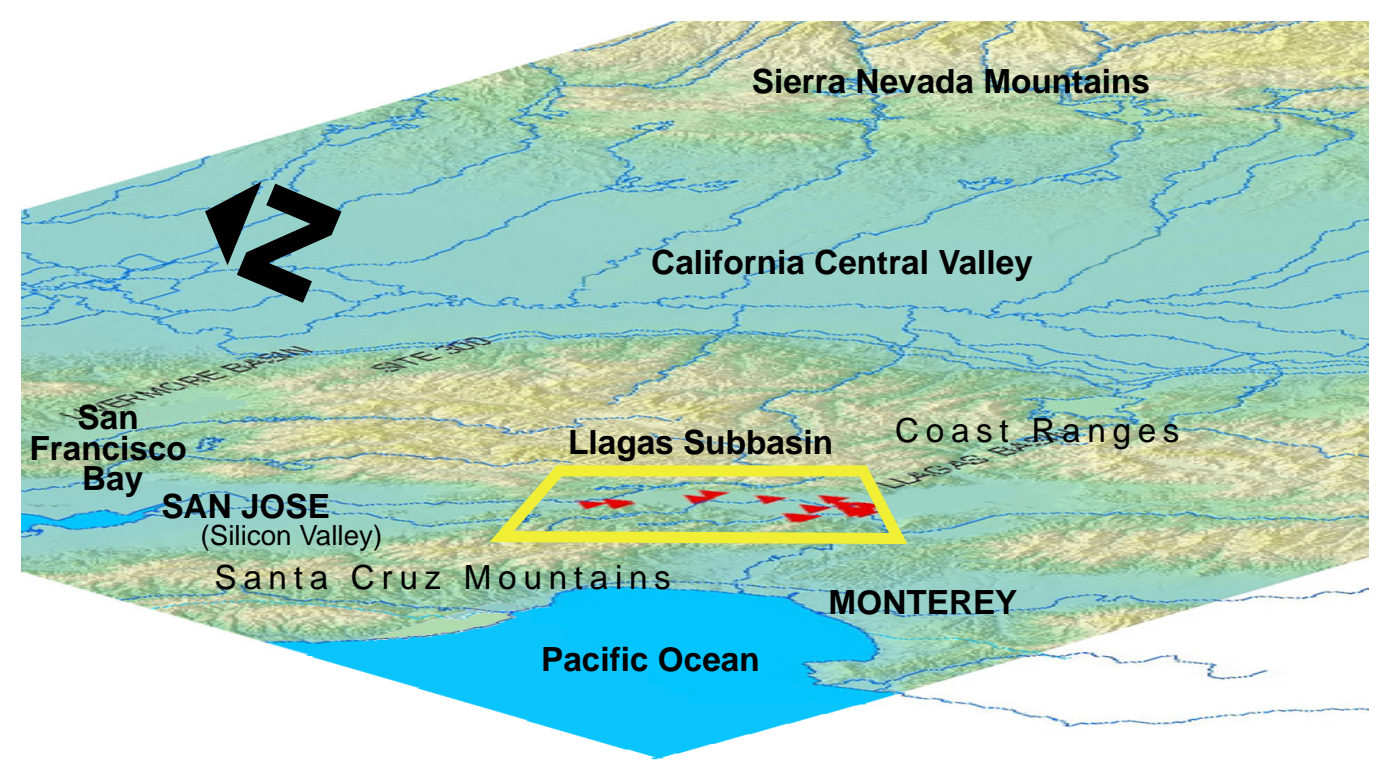

Figure 1. Bird's eye view of the Llagas subbasin location south of San Jose, California, looking northeastward.

50 years, these valley areas have undergone significant growth and urbanization due to their proximity to Silicon Valley, and groundwater provides the only source of water to some areas in the subbasin. The shallow zones are also threatened by widespread perchlorate contamination. Contamination in the shallow zones threatens deeper zones where increased water production is expected in the future to meet the demands of an increasing local population.

At its northern end, the subbasin extends from a groundwater divide (at its junction with the Coyote subbasin) to the south where it is bounded by the Pajaro River [7]. The subbasin is approximately $25 \mathrm{~km}$ long and ranges between 5 and $8 \mathrm{~km}$ wide. Annual precipitation ranges from less than $40 \mathrm{~cm}$ in the south to more than $60 \mathrm{~cm}$ in the north. Water level elevations (Fig. 2) indicate a southeasterly groundwater flow direction with significant natural recharge occurring where streams discharge into the subbasin south and northeast of Morgan Hill and west of Gilroy [10].

\section{MODELING STRATEGY AND FRAMEWORK}

Our reactive transport modeling approach focuses on the development of a hierarchical simulation framework that can be used as a means to assess the impacts of spatially variable nitrate loading, nitrate transport, and reactive (denitrification) processes between the water table and both shallow and deeper groundwater zones. Our simulation strategy 


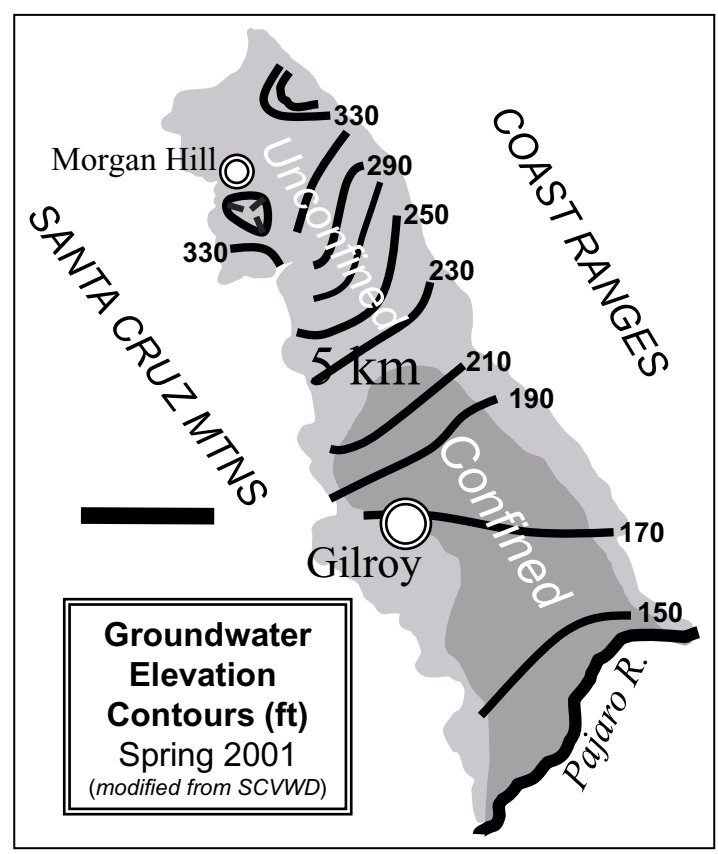

Figure 2. Map of Llagas subbasin showing groundwater elevation contours (in feet above sea level) for Spring, 2001. Modified from [10]. 
will be iterative and grounded, initially, in the development of a detailed geologic model. As discussed further below, flow model development will be guided by isotopic age dating measurements, noble gas tracer measurements, inverse geochemical models, and additional biogeochemical characterization of denitrification processes, as determined from both the field and laboratory. Ultimately, model simulations will allow the evaluation of important sensitivities and factors that control the flux, distribution, and residence times of nitrate in the subbasin and, thus, may form a basis for improving basin nitrate management strategies in the future.

\subsection{Geostatistical Simulation of Hydrostratigraphy}

The water bearing formations of the Llagas subbasin include Pliocene to Holocene age deposits of unconsolidated to semi-consolidated gravel, sand, silt and clay [7]. These include the deeper Santa Clara Formation and alluvial and alluvial fan deposits, which constitute the principal water producing zones. This and previous hydrogeologic interpretations $[7,11]$ depict the hydrostratigraphic architecture as consisting of thick, gently dipping, and laterally continuous layers composed of three principle hydrofacies: (1) coarse-grained materials, (2) fine-grained materials including lacustrine deposits, and (3) alternating thin and discontinuous layers gravel and silt or clay. In a hydrogeologic context, these three hydrofacies can be regarded as aquifers, aquitards, and aquicludes, respectively.

Geostatistical simulation methods can be used to generate representative three-dimensional "realizations" of alluvial hydrofacies architecture [12-14]. In this study, realizations are designed to replicate the patterns of heterogeneity evident in the Llagas subbasin aquifer system. These patterns are deduced from geologic cross sections $[7,11]$ and direct measurement of vertical transition probabilities from high-quality lithologic logs. Spatial variability of hydrofacies is quantified through a transition probability Markov approach [12-14]. The realizations are conditioned by lithologic logs, including driller's logs, and can be adjusted to reflect larger scale structural patterns or trends such as dips or transitions between formations, e.g., [16].

The richest source of data that describe hydrofacies architecture is found in drillers' logs, which, understandably, can be of variable quality. Over 300 drillers logs (Fig. 3) have been used to condition the geostatistical realizations developed in this study (Fig. 4). The size of the domain in this representation is $24 \mathrm{~km}(\mathrm{x}) \times 8 \mathrm{~km}(\mathrm{y}) \times 0.3 \mathrm{~km}$ (z). The spatial resolution is $100 \mathrm{~m}$ in the horizontal directions (x, y) and $2 \mathrm{~m}$ in the vertical (z), yielding over 2.8 million blocks in the model realization. Conditioning of the geostatistical realizations to drillers' logs data is accomplished through a novel technique that accounts for data inaccuracy through assigned correlations between the data and true lithology [15]. For example, if a particular driller's log is assumed absolutely correct in describing lithology, the assigned correlation is 1.0. Likewise, if the driller's logs is assumed completely inaccurate, or "random", the assigned correlation is 0.0 .

The geostatistical simulation algorithm attempts to preserve spatial correlation inferred 


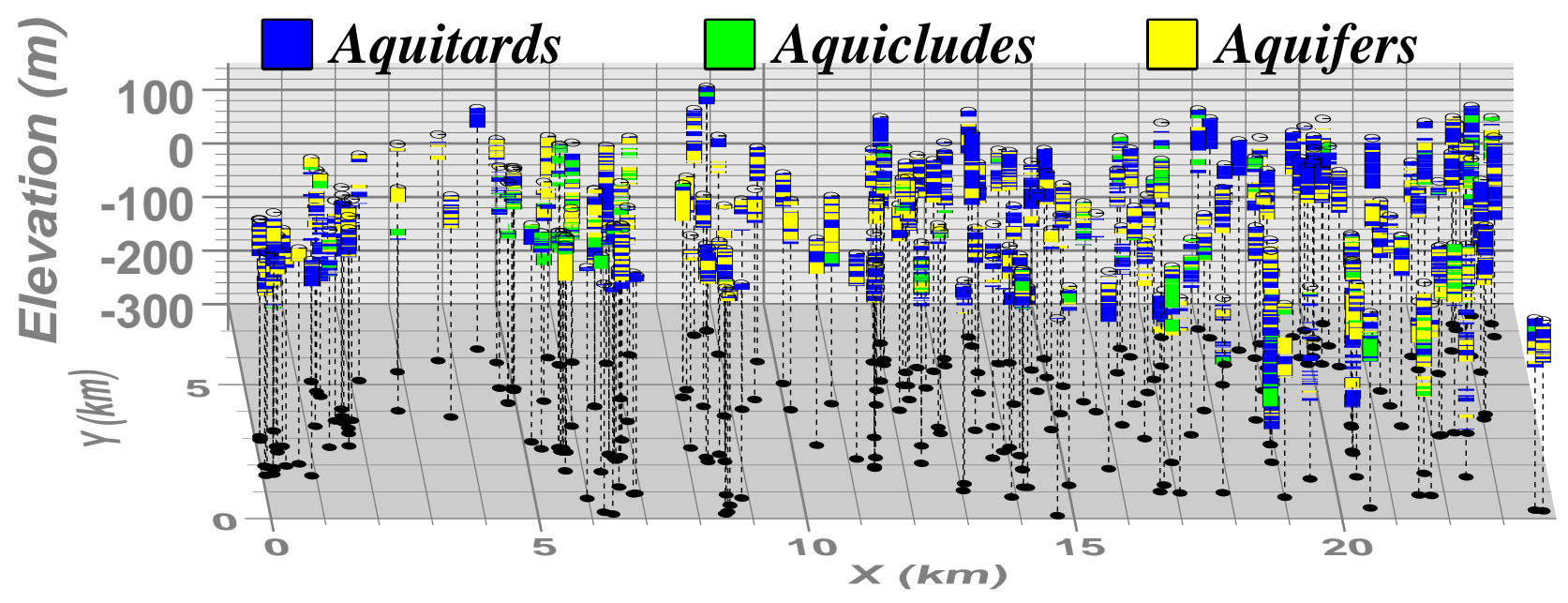

Figure 3. Driller's log lithologic data categorized as aquifers, aquitards, and aquicludes in Llagas subbasin (looking northeastward).

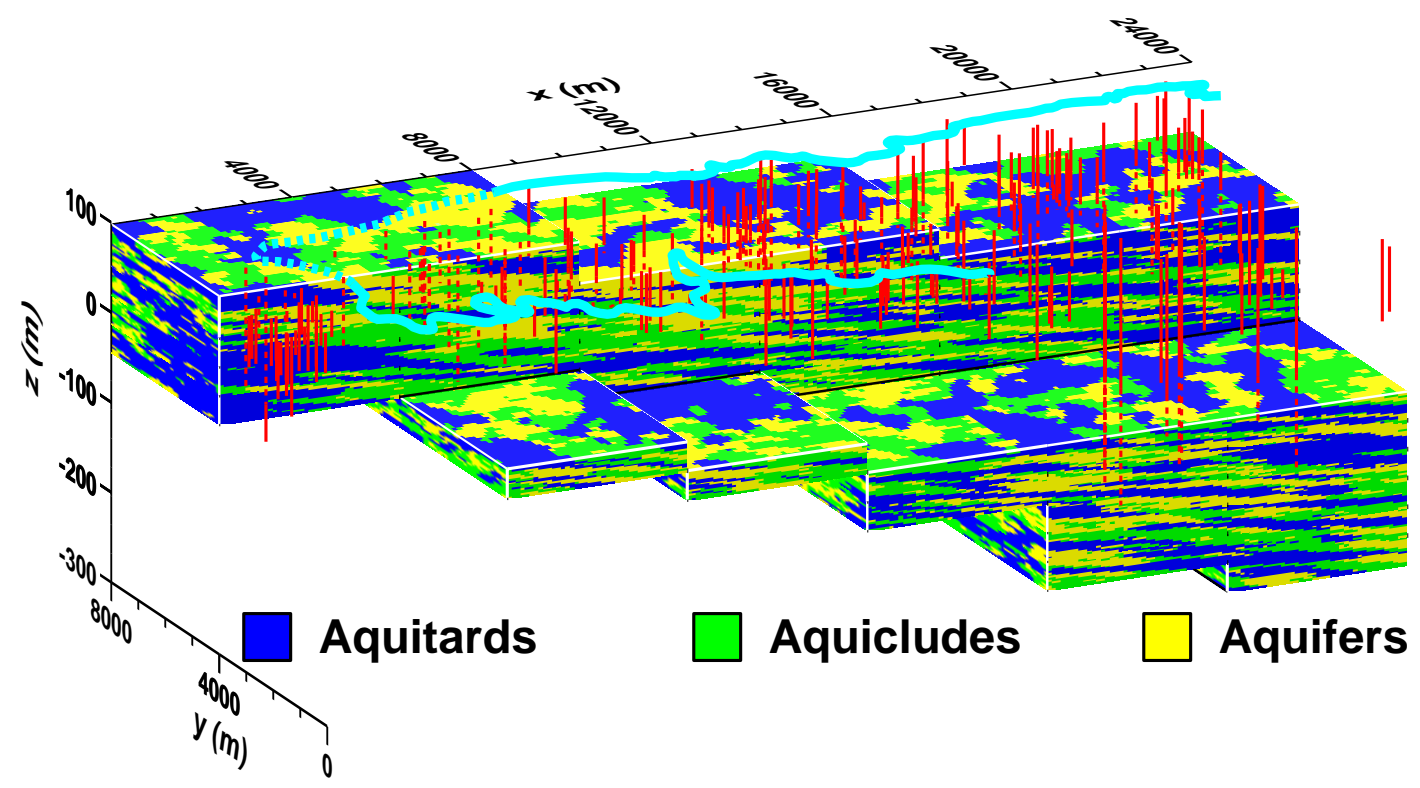

Figure 4. Example geostatistical realization of hydrofacies architecture in the Llagas subbasin, looking northeastward. The domain is $24 \mathrm{~km}$ long, $8 \mathrm{~km}$ wide, and $0.3 \mathrm{~km}$ deep, with a spatial resolution of $100 \mathrm{~m}$ in the horizontal directions and $1 \mathrm{~m}$ in the vertical. Red lines represent wells in Fig. 3. Light blue outline represents the subbasin boundary at the surface. 
from the hydrofacies data; thus drillers' log data are honored to varying degrees depending on data quality. In this manner, the better quality data exert a stronger influence on the realizations. Conversely, poor quality data do not force unrealistic stratigraphic relationships. In application to the Llagas subbasin lithologic data, assigned correlation for different driller's logs ranges between 0.3 to 0.7 , depending on quality of lithologic description. Assigned correlation of 1.0 was ascribed only to lithologic logs carefully described by hydrogeologists.

\subsection{Isotopic Age Dating and Source Identification of Groundwater}

Groundwater "age" represents the mean amount of time a groundwater parcel has resided in the saturated zone, isolated from any connection with the atmosphere. Groundwater ages can be used to understand travel times along flow pathways between recharge locations and sampling points, which are typically wells [16]. The water parcels collected in such a sample may be widely distributed in terms of their ages, largely as a function of the sampling length of the screened interval and dispersion and diffusion along flow pathways that reach the well [16].

Groundwater ages can be estimated from a combination of isotopic dating approaches: (1) tritium- ${ }^{3} \mathrm{He}$ ratios, based upon the amount of ${ }^{3} \mathrm{He}$ ingrown from the radioactive decay of tritium (an isotope of hydrogen incorporated in some water molecules), can be used to estimate the age of groundwater less than 50 years old; (2) raw tritium concentrations can be decay-corrected according to the tritium-helium age and compared with historical tritium concentrations in precipitation to indicate the fraction of water over 50 years old, and (3) radiogenic ${ }^{4} \mathrm{He}$ concentrations derived from the radioactive decay of uranium and thorium minerals in the subsurface can be used to estimate the age of the fraction of water over 50 years old.

In the Llagas subbasin, tritium- ${ }^{3} \mathrm{He}$ and ${ }^{4} \mathrm{He}$ groundwater age estimates were obtained from 13 wells (Fig. 5). In the Morgan Hill area, older tritium-helium ages generally correspond to older ${ }^{4} \mathrm{He}$ ages (Fig. 6). The younger tritium- ${ }^{3} \mathrm{He}$ age dates further refine wells vulnerable to water quality impairment. A sample from southeast Gilroy containing the youngest groundwater analyzed thus far may be influenced by recharge immediately to the west. Age versus depth relationships are difficult to infer because of long and multiple well screen intervals but stratified groundwater (younger, contaminated groundwater in the shallow section) is evident in wells with differing perforation intervals.

Several techniques can be used to infer the source of groundwater at a sampling point, or the source of nitrogen within the groundwater. For example, artificial recharge is being implemented in the northern portion of the Llagas subbasin using imported water from the San Francisco Bay Delta, which is fed by Sierra Nevada river flows. Because this water is depleted in its content of the ${ }^{18} \mathrm{O}$ isotope (incorporated in some water molecules), it is isotopically lighter than the recharge derived from local precipitation, and can be readily distinguished in groundwater. Recent ${ }^{18} \mathrm{O}$ measurements indicate that imported water is present in 6 of 12 wells sampled in the Morgan Hill area, while other wells in the Llagas 


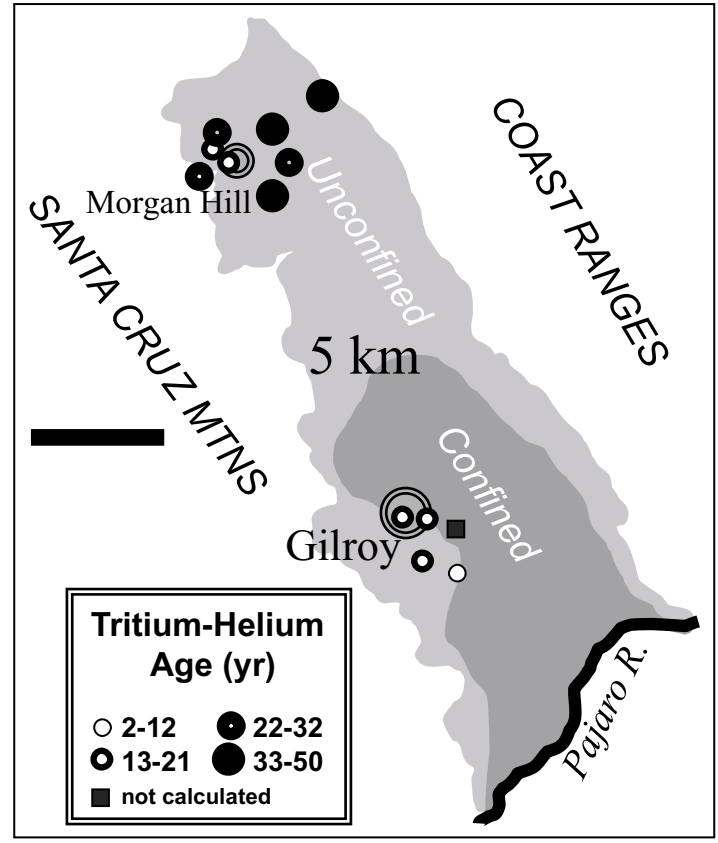

Figure 5. Tritium-helium groundwater age estimates for 13 samples obtained from Llagas subbasin. 


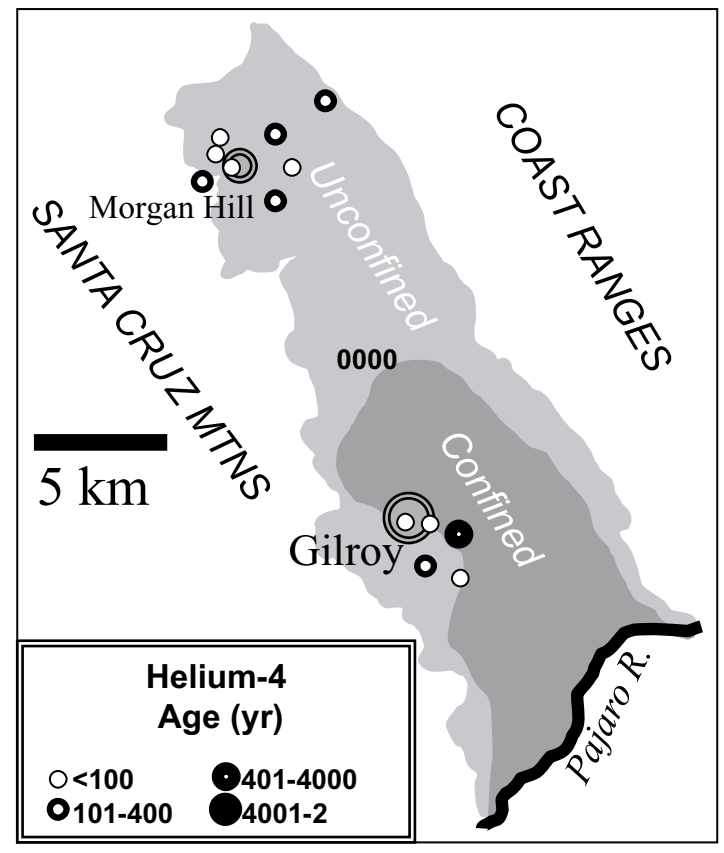

Figure 6. Helium-4 groundwater age estimates for 13 samples obtained from Llagas subbasin. 
subbasin indicate exclusively local recharge sources.

Measurements of dissolved air in groundwater samples (chiefly, $\mathrm{Ar}, \mathrm{N}_{2}$, and $\mathrm{O}_{2}$ ) and the fraction of the nitrogen isotope ${ }^{15} \mathrm{~N}$ present can also be used to assess whether excess nitrogen exists as a product of microbial denitrification along an upgradient flow path, as well as correlate nitrate nitrogen with potential nitrate sources above the water table.

Altogether, groundwater age estimates larger or smaller than 100 years can help distinguish groundwater sources subject to anthropogenic effects. The use of groundwater age dates along with estimates of recharge sources, dissolved air, and dissolved nitrogen can help identify realistic lateral and vertical flow paths and travel times for flow models, as well as document the existence of denitrification and potential sources of nitrate along these flow paths. The flow models, in turn, may provide insights on actual age distributions and depth relationships to improve interpretion of isotopic age estimates [16]. This synergy is useful for identifying aquifer zones susceptible to contamination, including the past and future impacts from nitrate loading.

\subsection{Geochemical Inverse Modeling}

Geochemical inverse modeling can be useful in relating groundwater quality observations at specific locations to potential reactions occurring along upgradient flow paths or streamlines. For example, the inverse component of the PHREEQC geochemical modeling code [17] uses mass balance constraints imposed on chemical reactions to infer the probability of an assumed reaction mechanism. In the Llagas subbasin, such geochemical constraints can be used to identify and check plausibility of reaction mechanisms along putative flow paths subject to nitrate loading. For example, oxidation reactions entailing suspected nitrate sources, such as animal fertilizers, will produce measurable changes in aquifer chemistry (e.g., increases in dissolved inorganic carbon, declines in pH, and elevated calcium and magnesium concentrations associated with carbonate mineral dissolution).

In Figure 7, nitrate concentrations show correlation with total calcium and magnesium concentration from several samples collected in the Llagas subbasin. The nitrate data appear to be clustered with respect to sodium concentration, a good indicator of total dissolved solids. The separation of the nitrate data with respect to total dissolved solids provides some means, albeit crude, for distinguishing different recharge sources and flow paths and, therefore, different nitrate sources. In the figure, three reaction mechanism models are compared that involve (1) organic fertilizer (e.g., $\mathrm{C}_{5} \mathrm{H}_{7} \mathrm{O}_{2} \mathrm{~N}$ ), (2) chemical fertilizer (e.g., $\mathrm{NH}_{4} \mathrm{NO}_{3}$ ), and (3) equal contributions of nitrogen from organic and chemical fertilizers on a molar basis (Combo). Comparison of the data to the models indicates that mixing of recharge water and nitrate loading subject to different reaction mechanisms contributes to the observed concentrations.

\subsection{Microbial Processes}

Microbially facilitated denitrification reactions will be incorporated into our transport model as field and laboratory data are gathered and interpreted. In addition to field 


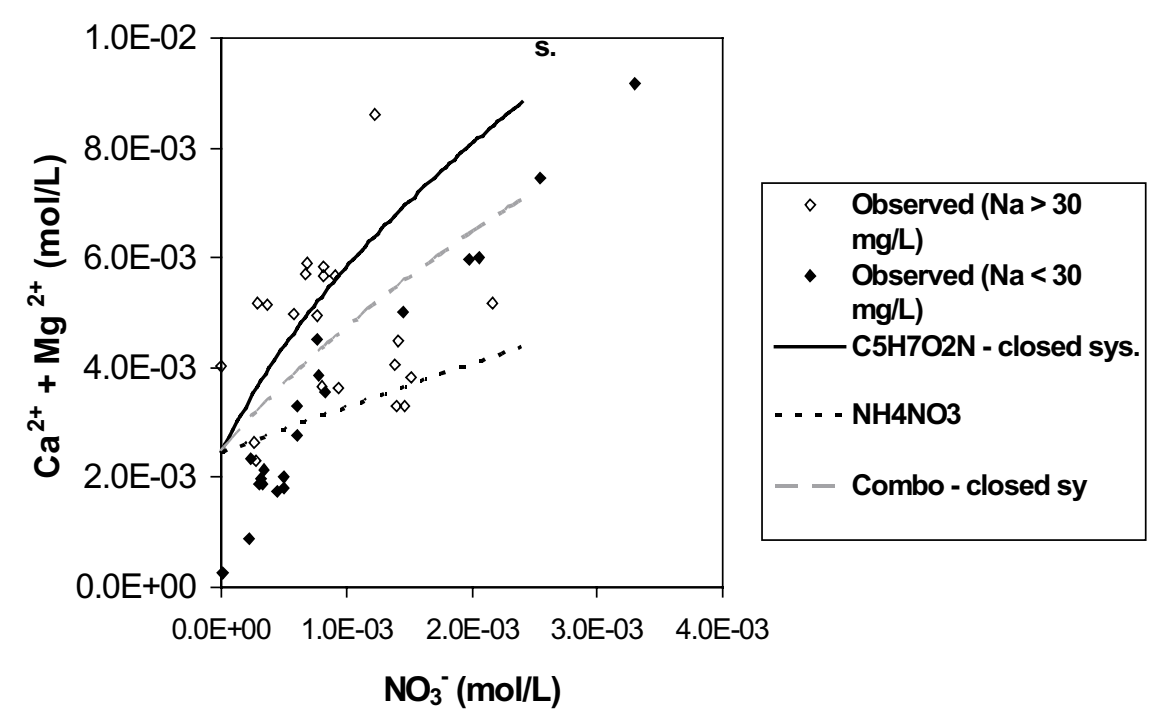

Figure 7. Comparison of nitrate to total calcium and magnesium concentrations, with possible nitrate source mechanism models.

data related to the identification of excess $\mathrm{N}_{2}$ nitrogen in groundwater, two primary kinds of biological data will be used to address denitrification kinetics: (1) populations of denitrifying bacteria in aquifer samples collected in the field and (2) specific denitrification rates (i.e., mass of nitrate reduced per bacterial cell per unit time) determined in laboratory studies. To determine populations of denitrifying bacteria in field-collected aquifer samples, we will use quantitative, real-time PCR (Polymerase Chain Reaction) analysis that targets a diagnostic denitrification gene; based on an average of one gene copy per bacterial cell, the population of denitrifying bacteria in the sample can be calculated. Specific denitrification rates will be determined for the two major classes of denitrifying bacteria: heterotrophs and chemolithoautotrophs. Heterotrophic denitrifying bacteria use dissolved organic compounds as electron donors and as sources of cell carbon. Chemolithoautotrophic denitrifying bacteria, which can dominate denitrification activity in subsurface environments that are oligotrophic (i.e., low in organic carbon), use reduced inorganic compounds as electron donors and carbon dioxide as a source of cell carbon. As has been documented at numerous field sites, chemolithoautotrophic bacteria in aquifers often use reduced iron- and/or sulfur-containing minerals (such as $\mathrm{FeS}$ or $\mathrm{FeS}_{2}$ ) as electron donors (e.g., [18]); such use of insoluble electron donors can render denitrification rates much slower for chemolithoautotrophs than for heterotrophs. 


\section{FLOW AND REACTIVE TRANSPORT MODELS}

\subsection{Hierarchical Flow Modeling Approach}

Within the Llagas subbasin, two types of flow models will be considered. Initially, a subbasin-wide model will be developed in order to reconcile the basic water balances in the system (natural and artificial recharge, pumping and natural discharge, groundwater age, and water levels), both in terms of their current and historical configurations. This model will encompass confined and unconfined zones in the subbasin (e.g., as in Fig. 4), and will incorporate a vadose zone component to improve coupling of recharge processes to groundwater flow. The model will also be sufficiently detailed to resolve and distinguish the geostatistical variability of hydrofacies identified in Fig. 4 (2.8 million nodes). Codes such as Parflow $[16,20]$ or NUFT [19] are being considered for this model.

More detailed, highly resolved submodels may be constructed in smaller portions of the subbasin volume, such as in the southern confined zone, as a means to more carefully study the effects of small-scale heterogeneity on transport and potential denitrification behavior. These models will be bounded by hydraulic conditions inferred from the subbasin model and will involve more highly resolved geostatistical detail within the three primary hydrofacies. Multi-million node simulations with Parflow will be required for these flow solutions.

Development and application of these models will be guided by isotopic age dating measurements, related groundwater and nitrogen source information, and inverse geochemical models. Apparent flow pathways inferred from these data must be reconciled with model simulations and the lithologic framework developed from the well observations. Conversely, the flow model and related transport simulations (below) will provide an important flow-path oriented framework for interpreting the isotopic measurements themselves, which are often derived from "mixed" water samples collected from wells with large screened intervals [16].

\subsection{Hierarchical Transport Modeling Approach}

Two types of transport models will be used in conjunction with both of the flow models mentioned in the previous section. On one level, particle based transport models (e.g., [21]) can be used to explore advection, dispersion, and time-of-flight (residence time) behavior for a small number of unreactive components in groundwater - such as nitrate or labeled recharge - and they can also be tailored to treat some types of simplified reactions, including denitrification.

To address more complicated behavior involving the transport and reaction of multiple dissolved species, especially in highly resolved flow systems, we will utilize a streamlinebased reactive transport model. In this approach, a three-dimensional transport problem is recast into a large number of independent one-dimensional reactive transport simulations that correspond in a one-to-one fashion to a large number of streamlines that have been extracted from a three-dimensional flow field (e.g., [22,23]). The streamline mapping procedure is involves a regridding process tailored specifically for transport simulations. 
In many cases, this approach can drastically improve computational efficiency because (1) one dimensional transport problems are inherently easier to solve, (2) solutions on different streamlines can be obtained in parallel, and (3) computations may be focused in subsections of the flow domain where transport is of specific interest. In addition, the particular one-dimensional reactive transport model can be selected independently, such as PHREEQC [17], and used to represent, for example, aqueous complexation, oxidationreduction processes, interphase transfer reactions (mineral precipitation and dissolution, ion exchange, and evolution of generated gases), and denitrification. The approach is largely limited to steady flow applications in which the importance of cross-streamline mass transfer (e.g., via transverse dispersion) is minimal.

\subsection{Nitrate Migration and Fate}

Ultimately, these models will be applied and tested iteratively to resolve and forecast nitrate loading and migration from one or more potential source areas, as documented in [8]. We expect to obtain improved perspectives and understanding of (1) the overall residence times of nitrate in the subbasin, especially as they pertain to selected source types, source locations, and proposed mitigation measures, (2) the potential role of denitrification as a sink mechanism for nitrate in the subbasin, in addition to natural discharge pathways, and (3) the potential for deeper zones of the subbasin to become contaminated with nitrate as a function of increased groundwater production in the future.

\section{REFERENCES}

1. E. C. Anton, J. L. Barnickol, and D. R. Schnaible. Nitrate in drinking water: Report to the Legislature, California State Water Resources Control Board, Division of Water Quality, Sacramento, Report 88-11WQ, 60 pp, (1988).

2. California Department of Water Resources, Sacramento. California's Groundwater, Bulletin 118, Draft Update (2003).

3. K. T. B. MacQuarrie and E. A. Sudicky. Multicomponent simulation of wastewaterderived nitrogen and carbon in shallow unconfined aquifers I. Model formulation and performance, Journal of Contaminant Hydrology, 47, 53-84 (2001).

4. K. T. B. MacQuarrie, E. A. Sudicky, and W. D. Robertson. Numerical Simulation of a fine-grained denitrification layer for remving septic system nitrate from shallow groundwater, Journal of Contaminant Hydrology, 52, 29-55 (2001).

5. M. van der Schans. Nitrogen leaching from irrigated dairy farms in Merced County, California: Case study and regional significance, Thesis report, Sub-deartment of Water resources, Wageningen University, The Netherlands (2001).

6. T. Harter, H. Davis, M. C. Mathews, R. D. Meyer. Shallow groundwater quality on dairy farms with irrigated forage crops, Journal of Contaminant Hydrology, 55, 287-315 (2002).

7. California Department of Water Resources, Sacramento. Evaluation of groundwater 
resources, South San Francisco Bay, Volume IV, South Santa Clara County Area, Bulletin 118-1, (1981).

8. Santa Clara Valley Water District, Santa Clara, CA. LLagas Groundwater Basin nitrate study, Nitrate source area identification (1994).

9. Santa Clara Valley Water District, Santa Clara, CA. Urban Water Management Plan: April, 2001, Santa Clara, CA (2001).

10. Santa Clara Valley Water District, Santa Clara, CA. Groundwater Conditions 2001 (2001).

11. Brown and Caldwell and Geotechnical Consultants, Inc. San Martin Area Water Quality Study, Phase 1 Report, submitted to County of Santa Clara, (1981).

12. Carle, S. F. A Transition probability-based approach to geostatistical characterization of hydrostratigraphic architecture: Ph. D. dissertation, University of California, Davis, 238 p. (1996).

13. Carle, S. F. Implementation schemes for avoiding artifact discontinuities in simulated annealing: Mathematical Geology, v. 29, p. 231-244 (1997).

14. Carle, S. F., E. M.Labolle, G. S. Weissmann, D. Van Brocklin, and G. E. Fogg. Conditional simulation of hydrofacies architecture: a transition probability/Markov approach: in Hydrogeologic Models of Sedimentary Aquifers, Concepts in Hydrogeology and Environmental Geology No. 1, G. S. Fraser and J. M. Davis, eds., Society for Sedimentary Geology, Tulsa, OK, 147-170 (1998).

15. Carle, S. F. Integration of soft data into categorical geostatistical simulation, Lawrence Livermore National Laboratory, Livermore, CA, Report UCRL-JC-153653 (2003).

16. Tompson, A. F. B., Carle, S. F., Rosenberg, N. D., and R. M. Maxwell. Analysis of groundwater migration from artificial recharge in a large urban aquifer: A simulation perspective, Water Resources Research, 35(10) 2981-2998.

17. Parkhurst, D. L., and C. A. J. Appelo. User's Guide to PHREEQC (Version 2) - A Computer Program for Speciation, Batch Reaction One-Dimensional Transport, and Inverse Geochemical Calculations. U. S. Geological Survey Water-Resources Investigations Report 99-4259 (2002).

18. Beller, H. R., V. Madrid, G. B. Hudson, W. W. McNab, and T. Carlsen. Biogeochemistry and natural attenuation of nitrate in groundwater at an explosives test facility. In Press, Applied Geochemistry (2004).

19. Nitao, J. J. User's Manual for the USNT Module of the NUFT Code, Version 2.0.1, Lawrence Livermore National Laboratory, Livermore, CA, Report UCRL-MA-130653 Rev. 1 (1999).

20. Jones, J. E., and C. S. Woodward. Newton-Krylov-Multigrid Solvers for Large-Scale, Highly Heterogeneous Variably Saturated Flow Problems, Advances in Water Resources, 24, 763-774 (2001).

21. Tompson, A. F. B and L. W. Gelhar. Numerical simulation of solute transport in three dimensional randomly heterogeneous porous media, Water Resources Research 26: 2541-2562 (1990). 
22. Pawloski, G. A., A. F. B. Tompson, and S. F. Carle, eds. Evaluation of the Hydrologic Source Term from Underground Nuclear Tests on Pahute Mesa at the Nevada Test Site: The CHESHIRE Test, Lawrence Livermore National Laboratory, Livermore, CA, Report UCRL-ID-147023 (2001).

23. Maxwell, R. M., C.Welty, and A. F. B. Tompson. Streamline-based simulation of virus transport resulting from long term artificial recharge in a heterogeneous aquifer, Advances in Water Resources 26, 1075-1096 (2003). 